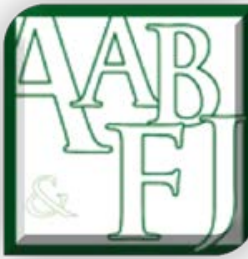

\title{
Belief and Investing: Preferences and Attitudes of the Faithful
}

\author{
Mark Brimble ${ }^{1 *}$, Victoria Vyvyan ${ }^{1}$, Chew $\mathrm{Ng}^{1}$
}

\begin{abstract}
This Australian study seeks to better understand the disparity between the positive attitudes towards Socially Responsible Investing (SRI) and the level of investment in SRI (Saulwick \& Associates 2001; Watmore \& Bradley 2001; Williams 2007; Arjalies 2010), by examining both the attitudes to SRI and the investment choices that are made. It is hypothesised that those who are more committed to religious belief principles are more likely to invest in SRI. To test this 322 people from two large Queensland organisations were surveyed in relation to their investment attitudes and preferences. Results show that those who are more religious are no more likely to invest in SRI, and that the level of importance placed on SRI and financial criteria are similar in most instances for the more and less religious. In addition, women who are religious place more importance on conservative general investment criteria than less or non-religious women.
\end{abstract}

Keywords: Socially Responsible Investing; Decision Making; Conjoint Analysis; Religion.

JEL: G19.

\footnotetext{
${ }^{1}$ Griffith Business School, Griffith University

* Corresponding author: m.brimble@griffith.edu.au
} 


\section{Introduction}

In recent years, there has been growing interest in an area of investment commonly referred to as Socially Responsible Investing (SRI). SRI, also known as ethical investment, involves investing in companies (in the form of direct share investments or managed funds) that screen out investments related to social concerns such as pollution, child labour, gambling and tobacco (NMI, 2003; Bengtsson 2008; Star 2008; Arjalies 2010). Such screening strategies are argued to resemble pro-social behaviour (Star 2008), which has seen a surge in interest with the popularisation of corporate social responsibility and increased public engagement in sustainability issues due to, among other things, climate change and the global financial crisis. Such social factors have also been shown to influence investment decision-making (Williams 2007). The growth of interest in the United Nations Principles of Responsible Investment (UNPRI, 2012) is perhaps testament to this.

However as SRI is influenced by individual values and beliefs, it is difficult to describe the term definitively (Tippett \& Leung 2001). This is complicated by the significant variation across countries in terms of operationalisation of SRI and the different levels of take-up (Arjalies 2010; Williams 2007). In Australia the invested capital is significant with AUD \$16.15 billion allocated to responsible investment (managed investment portfolios, community finance, green loans and investment portfolios of charities) (RIAA 2010). Of this, AUD \$15.41 billion was in managed investment funds, and one such fund is Glebe Asset Management, which invests according to Christian principles. This style of managed fund is not confined to Australia, with international equivalents such as The Timothy Fund in the US, which has an investment charter that screens against a wide range of activities that they view as unChristian, including alcohol, pornography, abortion and 'non-married lifestyles'. Another is fund manager Amana Mutual Funds Trust which invests according to Islamic principles.

The increased growth of SRI has also attracted the attention of regulators who aim to ensure that adequate disclosures concerning SRI information are provided to investors. For example, the Financial Services Reform Act 2002 requires that investment products disclose "the extent to which labour standards or environmental, social or ethical considerations are taken into account in the selection, retention or realisation of the investment" [S. 1013D (1) (1) of the Corporations Act 2001]. In addition, the Australian Securities and Investments Commission (ASIC) SRI Disclosure Guidelines require the provision of this information to clients by advisors.

Globally, this increased growth in SRI is supported by a significant number of guidelines, industry standards and voluntary codes of conduct which have been growing. These include the UNPRI, the Equator Principles, Investor Group on Climate Change, UNEP Finance Initiative and ESG Research Australia, all of which serve to maintain the interest in and growth of SRI.

In addition to opportunity, the performance of SRI is at least on par with other managed funds (Wright 2003; Jones 2009; Barnato 2010; Potts 2010). There have been a number of studies using a variety of methods, indexes and measurements of risk-adjusted returns which have concluded that there is no significant difference between the performance of SRI managed funds and conventional managed funds (Bauer, Koedijk \& Otten 2002; Cummings 2000; Guerard 1997; Kreander et al. 2002; Benson, Brailsford \& Humphrey 2006; Anderson \& Myers 2007; Cortez, Silva and Areal, 2009). Interestingly, the 2010 report of the Responsible Investment Association of Australia showed that responsible investment funds (Australian Share Funds and Overseas Share Funds) outperformed the average "mainstream" fund over 1, 3, 5 and 7 year investment horizons (RIAA 2010). 
Despite numerous SRI investment opportunities, positive performance outcomes and increased media coverage, there has been comparatively little support in terms of dollars invested in SRI managed funds. For example, out of the almost AUD \$926.8 billion in managed investment funds in Australia (as at June 2010), only AUD \$15.41 billion of this was in responsible investment portfolios. This represents a mere $1.66 \%$ of the managed funds sector. In contrast, several Australian studies (KPMG/Resnick 2000; Saulwick \& Associates 2001; Watmore \& Bradley 2001) have shown that over half of those surveyed would consider SRI as part of their investment portfolio. This would suggest that there is a gap between the attitudes and actions of investors. To date, there has been very little academic research that has examined or sought to explain the difference between attitudes and preferences (or choices) within the context of investor decision-making and SRI.

In an attempt to offer some explanations on this phenomenon, Vyvyan, Ng \& Brimble (2005) argued that the results of these studies may have been influenced by a demand effect and/or social desirability bias (Mohr, Webb \& Harris 2001) since only the attitudes of investors were examined. In the context of SRI, individuals are likely to give a positive response (the so-called 'good citizen' image) if only their attitudes towards this kind of investment are asked. They therefore hypothesized that there is a difference between investors' attitudes and stated preference (or choice) in SRI. ${ }^{2}$ In their study, they found that while women placed higher importance on SRI criteria (such as: "sin" screens - tobacco, alcohol and gambling; environmental screens; or social issues - child labour and animal rights) in the attitudes section than men, those attitudes had little influence on their stated investment preference. In fact for both men and women, their investment decisions were based on some of the traditional investment decision-making criteria, including past performance, star rating and fees. A later study found that there was a significant difference in their attitudes, with environmentalists placing more importance on SRI investment criteria. However, there was no significant difference between environmentalists and nonenvironmentalists when their preference was analysed, with the environmentalists placing a higher importance on traditional financial performance criteria than SRI criteria, making their choices similar to those with the lowest level of environmental activism.

Interestingly, the issue of religiosity is yet to be explored, and given that the roots of SRI stem from religious beliefs thousands of years ago (Kinder and Domini, 1997; Knoll 2002; Schwartz 2003; Bengtsson 2008), and that those beliefs have been a driving force behind the creation of managed funds that invest according to religious principles, it is important to also understand the impact of religious belief and values on individuals' attitudes and preferences towards SRI. Indeed, the role that religiosity plays in influencing ethical attitudes is well documented in such studies as academic misconduct (Barnett, Bass \& Brown 1996), corporate social responsiveness orientation (Angelidis \& Ibrahim 2004), environmentalism (Wolkomir et al. 1997), insider trading (Terpstra, Rozell \& Robinson 1993), predictors of ethical awareness (Conroy \& Emerson 2004) and Islamic Finance (Brimble, Kremmer \& Tahir 2010). These studies have found that the extent of religiosity is generally linked to higher ethical attitudes. However, Agle and Van Buren (1999) found that religious practice and Christian beliefs had a weak relationship to attitudes towards corporate social responsibility.

In view of the above conflicting results and the close association between religious belief and SRI development, there is a need to further examine the disparity of investors' positive attitudes towards SRI and real investment decisions using religious belief as a determinant. This study examines the role that religion plays in the investment decision-

\footnotetext{
2 See also Clark-Murphy and Soutar (2003). While their study was not in SRI, they compared investors' attitudes and preference in investment allocation decision situations and found that there was a difference between their participants' attitudes and stated preference.
} 
making process and how this influences the take-up of SRI products. This provides an opportunity to more rigorously test the impact of religiosity on investment decisions given the evidence suggesting that religious individuals may be more inclined to invest in such products. This provides a hypothesis that religiosity will have an impact in terms of the investment decisions relative to SRI investments. Furthermore, extending our understanding of the choices investors make is not only important for the fund management industry, in terms of developing and marketing their products, but it also has public policy implications in terms of funding retirement, financial advice and product disclosure. This is particularly pertinent in the post-GFC period where the role of financial advice, investment management and financial regulation is being questioned.

To achieve this, 322 people were surveyed in relation to their investment attitudes/criteria and then asked to put these into practice through an asset allocation experiment. Using conjoint analysis, the attitudes and investment decisions are compared to determine which factors actually drive decision-making. The results indicate that religiosity does in fact play an important role in investment decision-making with the issues that are traditionally sensitive/important to religious groups such as abortion, contraception and donation to charities being more important investment attributes to those who are more religiously active in comparison to those who are not. Furthermore, religiously active females appear to be more conservative and risk adverse, preferring companies that are household names and old established companies. Interestingly, while these factors are more important, they are subordinate in ranking to performance characteristics. This is also borne out in the investment preferences task, demonstrating that there is no evidence of an attitude-behaviour gap beyond that which can be explained by gender. This suggests that investors are rational, wealth-maximising market participants irrespective of their attitudes or gender, therefore dispelling stereotypical behavioural patterns and social desirability bias in terms of investment decision-making. Consequently, we suggest that traditional rational finance theory is alive and well.

This paper contributes to the literature in four ways: (1) extending the behavioural finance literature in terms of factors that influence investment decision-making in the Australian market; (2) providing further evidence in relation to the impact of religiosity in investment decision-making; (3) examining the difference between investors' attitudes and actual investment behaviour towards SRI products, which has received little attention in the literature to date; and (4) applying an advanced decision-based methodology, common in the consumer and marketing literature, to a behavioural finance setting.

The remainder of this paper is set out as follows. The next section provides a brief review of the development of SRI, and the section following that discusses the research method. This is followed by analysis and a discussion of the results. Concluding remarks and possible future research directions complete the paper. 


\section{The Development of SRI}

A version of social investment may have been in existence some 3,500 years ago (Schwartz 2003). Ancient Jewish law prohibited a Jew from producing or selling non-kosher foods, whether as a sole proprietor or as a partner of a business. The law also forbade Jews from becoming partners in business transactions taking place on the Sabbath (Schwartz 2003). While under the influence of the Catholic Church doctrine, individuals refused to do business with people engaged in the practice of usury ${ }^{3}$ during the $13^{\text {th }}$ and $14^{\text {th }}$ centuries. In the $18^{\text {th }}$ century, the Religious Society of Friends, better known as the Quakers, refused to profit from war or slave-running activities (Kinder, Lydenberg \& Domini 1993; Hutton, D’Antonio \& Johnson 1998; \& Schwartz 2003). Indeed Quaker business proprietors (such as Rowntree and Cadbury) were leaders in humanitarian initiatives and ethical business during this period (Tippett \& Leung 2001).

In the 1920s, the Methodists began investing in the share market, when they declared that it was no longer akin to gambling. However, they refused to invest in stock that profited from gambling or alcohol. In 1928, the first managed fund that invested according to SRI principles (by not investing in companies involved in alcohol or tobacco), the Pioneer Fund, was established in the US. However, progress was slow and support for this Fund mainly came from those who wished to invest according to their religious beliefs and values (Kinder, Lydenberg \& Domini 1993).

The modern era for SRI development commenced in the late 1960s with the rise of civil rights, women's rights and consumerist movements, the Vietnam War and social legislation (Kinder \& Domini 1997; Henningsen 2002). The next wave of SRI was driven by the challenges posed by the Apartheid policies in South Africa. Divestiture of investment in South Africa began in 1976, as a response to concerns about Apartheid; this period lasted until 1993 (Kinder, Lydenberg \& Domini 1993). Some believed at the time that SRI would quietly fade once investment in South Africa resumed at the end of Apartheid. However, this did not occur (Hutton, D’Antonio \& Johnson 1998; Becker \& McVeigh 1999).

Major drivers for the continuing interest in SRI following the end of Apartheid have been the growing awareness of environmental issues and a greater focus on social concerns such as labour and human rights (Schwartz 2003). Since then, there has been an explosion of growth in the number of managed funds offering investments along SRI principles, which include, for some funds, screening based on religious principles. Specialist research organisations (such as Ethical Investment Research Services and the Sustainable Investment Research Institute, amongst others) have been developed to support the SRI industry. A range of indexes, including the Dow Jones Sustainability Index in the US, the Jantzi Social Index in Canada, and the FTSE4Good Index in Britain, have also been developed to track SRI performance.

In recent times the development of a range of issues has further promoted SRI. Chief among these is the wider acceptance of a role for corporations in addition to the maximisation of shareholder wealth (Ruf et al. 2001). This is referred to as Corporate Social Responsibility and is underscored by the acceptance that environmental, social and governance (ESG) issues impact the financial performance of the firm. This further suggests that investors are increasingly influenced by a company's environmental and social performance and such considerations impact on investment decisions (Ambachtsheer 2005; The Mays Report 2003; Dale 2007; Williams 2007). This has led to a 'mainstreaming' of SRI (and responsible investment more broadly) that will support the growth of SRI over time (Arjalies 2010).

\footnotetext{
${ }^{3}$ Lending at an exorbitant rate of interest.
} 
In Australia, there have been several studies since 2000 that examine investors' attitudes towards SRI and other related issues. For example, KPMG/Resnick (2000) found that environmental concerns and human rights were amongst the most important factors influencing SRI decision-making. In a study of 1,000 shareholders' attitudes towards various investment issues, Saulwick \& Associates (2001) found that $45 \%$ of their sample had heard of SRI and that $80 \%$ of those indicated that they would be prepared to invest in SRI. The Rothschild Report (Watmore \& Bradley 2001) supported this, finding that over 50\% of the participants interviewed were willing to include SRI in their portfolio. A similar finding was reported in the ASSIRT Proactive Investor Survey in 2002. All of these Australian industry studies evidence a strong support for the idea of investing in SRI.

\section{Research Methodology}

The aim of this study is to examine whether the level of individuals' religious beliefs and activism influence their attitudes to SRI criteria and their stated investment choices. In particular, we examine whether those who practise their religious beliefs to a greater extent are more likely to engage in activities that promote ethical and moral values, and hence are more likely to invest in SRI. To test this hypothesis, a research instrument that measured both attitudes and preferences was designed. A multivariate decision method used widely in consumer and marketing research, conjoint analysis, was then used to analyse this relationship.

\section{Development of the Research Instrument}

This study applies conjoint analysis, a multivariate decision method, since it is able to measure the relative importance of factors (or attributes) and levels of factors for alternate products at both the individual and the group level. In essence, the technique requires participants to choose between products, or assign rankings/ratings to the products according to their liking for that product or service (Hair et al. 1998). By making trade-offs between needs and values, the motivations underpinning investment choice are revealed. Through the calculation of utility scores for each of the factor levels (components of the product or service) it is possible to determine how important each of the attributes of a product are relative to each other. In order to achieve a realistic assessment of the importance of SRI criteria in investment decisions, a fractional factorial main effect design, which eliminates interaction effects between the factors, was generated using SPSS Categories Orthoplan. Consistent with prior research, training ${ }^{4}$ and holdout ${ }^{5}$ profiles were included in order to measure the predictability of the model (Hair et al. 1998).

The first section of the research instrument contained the investment preferences experiment (conjoint analysis) in which the task was to evaluate each of the 22 hypothetical funds and allocate an amount between AUD \$0 and AUD \$5,000 according to how much they liked the fund. While there was no overall limit for the exercise, no more than AUD $\$ 5,000$ could be invested in any one fund. For conjoint analysis to have efficacy, the task, factors and factor levels must be realistic. Hence, researching the literature and real life

\footnotetext{
${ }^{4}$ Training profiles are used to illustrate to participants the required process of selecting investment alternatives and are not included in the actual sample.

${ }^{5}$ Holdout profiles are (in this case) investment options that are included as checks to ensure that respondents are
not selecting investment alternatives in a nonsensical fashion.
} 
investment products, focus groups and pilot testing the research instrument were used to ensure the instrument would provide reliable data. As a result of this the following factors were identified as important to investment decision-makers: performance; fees; star rating; company type; and companies that the fund invests in. Performance levels and fees charged were based on actual managed funds which are available to retail investors in Australia (ASSIRT 2002), while the factor levels relating to SRI were selected from the importance ranking of the KPMG/Resnick survey (2000) and Watmore and Bradley (2001). Table 1 shows each of the factors and the levels for each factor that were used in this study.

Table 1: Factors and Levels used in the Conjoint Analysis Design

\begin{tabular}{|c|c|}
\hline Factors & Levels \\
\hline \multirow[t]{4}{*}{ Performance } & $8 \%$ \\
\hline & $10 \%$ \\
\hline & $12 \%$ \\
\hline & $14 \%$ \\
\hline \multirow[t]{3}{*}{ Star rating } & Not rated \\
\hline & 2 Star \\
\hline & 4 Start \\
\hline \multirow[t]{2}{*}{ Fees } & $0 \%$ entry fee, $2.49 \%$ yearly fee, $4 \%$ exit fee \\
\hline & $4 \%$ entry fee, $1.95 \%$ yearly fee, $0 \%$ exit fee \\
\hline \multirow[t]{2}{*}{ Company type } & Blue Chip companies only \\
\hline & Smaller Companies Only \\
\hline \multirow[t]{4}{*}{ Invests in } & Companies must have good environmental management policies and practices \\
\hline & Companies must have good management \\
\hline & Companies must have good prospects for growth \\
\hline & Companies must have good relationships with employees and unions \\
\hline \multirow[t]{4}{*}{ Does not invest in } & Companies must not have Boards that are dominated by executive directors. \\
\hline & Companies must not produce or sell weapons or defence technologies \\
\hline & Companies must not produce or sell alcohol, tobacco or gambling \\
\hline & Companies must not have a loss in the last year. \\
\hline
\end{tabular}

This table lists the factors and factor levels used in the study to assess the attitudes and investment preferences of 322 survey respondents.

The two factors, which contained SRI criteria, 'Invests in' and 'Does not invest in', represented the common approaches to SRI screening (positive and negative) that are used by fund managers. To minimise the potential impact of social desirability bias (Chung \& Monroe 2003) or demand effect (Neumann 2003), SRI components were kept to 4 of the 19 levels so that there was less chance that participants were aware of the purpose of the questionnaire. Indeed, the questionnaire made no reference to SRI in its research title or instructions. Religious affiliation was measured using four questions related to regularity of attending church services and events, giving money to the church or religious group, frequency of worshipping or practicing belief, and attending special study or other groups arranged by the church or religious group. 
Table 2

Descriptive Statistics

\begin{tabular}{|c|c|c|}
\hline Demographic & Sample & \\
\hline Gender & REL 1 (n = 185) & REL 2 (n = 137) \\
\hline Male: & 39.7 & 41.6 \\
\hline Female: & 60.3 & 58.4 \\
\hline \multicolumn{3}{|l|}{ Age } \\
\hline$<26$ yrs & 10.3 & 5.1 \\
\hline$>27-35$ yrs & 22.7 & 13.9 \\
\hline $36-45$ yrs & 31.4 & 28.5 \\
\hline $46-65$ yrs & 21.6 & 27.0 \\
\hline$>66$ yrs & 14.1 & 25.6 \\
\hline \multicolumn{3}{|l|}{ Income } \\
\hline$<\$ 15,000:$ & 0.6 & 5.9 \\
\hline$\$ 15,001-\$ 30,000:$ & 7.4 & 8.1 \\
\hline$\$ 30,001-\$ 45,000:$ & 15.3 & 14.8 \\
\hline$\$ 45,001-\$ 60,000:$ & 21.0 & 12.6 \\
\hline$\$ 60,001-\$ 75,000:$ & 18.2 & 15.6 \\
\hline$\$ 75,001-\$ 90,000:$ & 12.5 & 13.3 \\
\hline$>\$ 90,001:$ & 25.0 & 29.6 \\
\hline \multicolumn{3}{|l|}{ Education } \\
\hline Post Graduate Qualification: & 46.7 & 43.1 \\
\hline Under Graduate Qualification: & 27.7 & 32.8 \\
\hline High School: & 12.0 & 10.9 \\
\hline Technical Education: & 13.0 & 12.4 \\
\hline Primary School: & 0.5 & 0.7 \\
\hline \multicolumn{3}{|l|}{ Culture } \\
\hline Australian: & 83.2 & 84.7 \\
\hline UK/Ireland: & 5.9 & 2.2 \\
\hline Other: & 10.9 & 13.1 \\
\hline \multicolumn{3}{|l|}{ Religious Affiliation } \\
\hline Christianity: & 40.7 & 85.2 \\
\hline No Religion: & 53.8 & 3.0 \\
\hline Other: & 5.5 & 11.8 \\
\hline \multicolumn{3}{|l|}{ Investment Participation } \\
\hline Direct Shares: & 42.2 & 49.6 \\
\hline Managed Funds: & 34.1 & 43.8 \\
\hline Personal Superannuation: & 18.4 & 23.4 \\
\hline No-Investments: & 25.9 & 13.9 \\
\hline
\end{tabular}

This table contains summary descriptive statistics for a sample of 322 survey respondents.

In the second section of the survey, participants were asked to indicate the level of importance that they attached to a range of SRI and other investment decision-making criteria. The levels of participant's practicing of their religious beliefs, his/her attitudes to investing in general and beliefs about SRI, and their attitudes related to both general investment criteria and SRI criteria were also included in this section. In the third section, participants were asked to provide some demographic details, including whether they already invested in SRI managed funds or superannuation options, and whether they would consider investing in SRI in the future. Based on responses from the pilot testing, the average time to complete the experimental task was around 20 minutes. 
To obtain information about investor attitudes and preferences in relation to SRI, 2,000 employees and members of two large Queensland organisations were surveyed. 322 usable questionnaires were returned, ${ }^{6}$ representing a response rate of approximately $16 \% .{ }^{7}$ Based on participants' responses to 4 questions, the sample was partitioned into two groups (above and below the mean of 4.99) one comprising those who indicate that they actively practice their religious beliefs ( $R E L 2$ ) and those who do so to a lesser extent (REL 1). Descriptive statistics are presented in Table 2.

There are approximately the same ratio of men and women in REL $1(\mathrm{n}=185)$ and REL 2 (n = 137), however REL 2 is older than REL 1, with 81.1\% of this group aged over 36 years (67.1\% REL 1). Culture and education are similar for both groups, and the slightly greater income levels and investment participation of REL 2 may reflect the age difference of the groups rather than their prosperity. As expected, REL 2 has $97 \%$ of the treatment group disclosing religious affiliation, and in contrast REL 1 has 53.8\% disclosing that they have no religion.

\section{Results and Discussion}

\section{Attitudes}

The attitude section of the questionnaire measured a range of SRI and general investment criteria on a 5-point Likert scale. ${ }^{8}$ Table 3 presents summary results for the REL 1 and REL 2 groups and illustrates little difference between the means of most of the variables. In fact, of the 25 variables only 6 have statistically significant different mean scores. Furthermore, the top 5 attributes are the same for both groups, and 9 of the top 10 are the same for both groups, including 'Good waste management practices' as an important attribute to the nonreligious group ( $R E L 1$ ), and 'Australian firms' as an important attribute to the religious group (REL 2). Thus the results, in terms of attitudes to investment attributes, are relatively similar.

\footnotetext{
${ }^{6}$ In total 369 surveys were returned, however 47 were rejected because they had pages missing or did not complete essential parts of the survey.

${ }^{7}$ Considering the complexity and nature of this research, the low response rate was somewhat expected. This is however not uncommon in this type of literature as per, Forster and Fox (2008).

${ }^{8} 0=$ not important, 1 = little importance, 2 = some importance, 3 = much importance, 4 = great importance.
} 
Table 3

Attitudes to Financial, General, Social, Ethical and Information Criteria

\begin{tabular}{|c|c|c|c|c|c|}
\hline \multirow[t]{2}{*}{ Investment Criteria } & \multicolumn{2}{|c|}{ REL 1} & \multicolumn{2}{|c|}{ REL 2} & \multirow{2}{*}{$\begin{array}{l}\text { Mean } \\
\text { Diff (\%) }\end{array}$} \\
\hline & Mean & Rank & Mean & Rank & \\
\hline \multicolumn{6}{|l|}{ Financial Criteria } \\
\hline Perform above the average & 2.77 & 3 & 2.88 & 2 & 3.82 \\
\hline Good rating from analysts & 2.81 & 2 & 2.74 & 3 & -2.55 \\
\hline Low entry fees & 2.62 & 5 & 2.61 & 5 & -0.38 \\
\hline Low ongoing fees & 2.84 & 1 & 2.96 & 1 & 4.05 \\
\hline \multicolumn{6}{|l|}{ General Criteria } \\
\hline Australian & 2.15 & 14 & 2.49 & 9 & $13.65^{* *}$ \\
\hline Household names & 1.64 & 20 & 1.97 & 19 & $16.75^{* *}$ \\
\hline Old established companies & 1.74 & 19 & 2.07 & 18 & $15.94^{* *}$ \\
\hline \multicolumn{6}{|l|}{ Social and Ethical Criteria } \\
\hline Does not produce or sell alcohol & 1.34 & 22 & 1.62 & 23 & 17.28 \\
\hline Does not produce or sell weapons or defence & 2.23 & 13 & 2.42 & 12 & 7.85 \\
\hline Does not produce or sell tobacco & 2.05 & 17 & 2.08 & 17 & 1.44 \\
\hline Sponsor the arts & 1.25 & 23 & 1.36 & 24 & 8.09 \\
\hline Donate to charities & 1.62 & 21 & 1.88 & 20 & $13.83^{* *}$ \\
\hline Are not involved in abortion services & 0.73 & 24 & 1.88 & 20 & $61.17^{* *}$ \\
\hline Good waste management practices & 2.38 & 10 & 2.37 & 13 & -0.42 \\
\hline Good relationships with indigenous people & 2.07 & 16 & 2.17 & 15 & 4.61 \\
\hline Treat all workers fairly & 2.43 & 9 & 2.50 & 8 & 2.80 \\
\hline Environmental management policies and practices & 2.61 & 6 & 2.60 & 6 & -0.38 \\
\hline Does not pollute & 2.70 & 4 & 2.74 & 3 & 1.46 \\
\hline Good relationships with local communities & 2.28 & 11 & 2.46 & 11 & 7.32 \\
\hline Support equal opportunity for all workers & 2.47 & 8 & 2.47 & 10 & 0.00 \\
\hline Does not produce or sell contraception & 0.46 & 25 & 0.76 & 25 & $39.47^{* *}$ \\
\hline Does not experiment on animals & 2.49 & 7 & 2.58 & 7 & 3.49 \\
\hline \multicolumn{6}{|l|}{ Information Criteria } \\
\hline A financial planner recommended the investment & 2.28 & 11 & 2.29 & 14 & 0.44 \\
\hline Good report in a magazine or newspaper & 2.08 & 15 & 2.16 & 16 & 3.70 \\
\hline A friend recommended the investment & 1.76 & 18 & 1.65 & 22 & -6.67 \\
\hline
\end{tabular}

This table presents summary results on the attitudes of investors to investments. Column 1 (Investment Criteria) contains characteristics of investments which survey respondents allocated an importance score to using a 5 point scale where 5 is highly important and 1 is not important in terms of considering that item when selecting an investment. The mean and rank of the mean results for the treatment groups REL 1 and REL 2 are presented in Column 2 to Column 5 with Column 6 presenting the difference between the means.

** represents a significant difference between the means of the importance ratings of the REL 1 and REL 2 respondents at the $p=0.01$ or greater level, based on a two tailed $T$-test. 
In terms of the importance of the individual variables the "Financial Criteria' appear to be the key criteria that the survey participants for both groups are concerned with as indicated by the high mean scores and rankings. Therefore, both groups appear to be first and foremost concerned with investments that offer relatively high performance. The agreement between the groups is not evident in the group of variables 'General Criteria' however, with the variables all significantly different at the $p=0.01$ level. For each of these three variables, REL 2 place more importance on companies that are Australian, companies that are household names and old established companies. This seems to suggest that the more religious group are somewhat more conservative, or risk adverse that the less religious group. In the "Ethical and Social Criteria', the results showed that there were significant differences between the level of importance that those in REL 1 and REL 2 assigned to 3 of the 15 variables in this group, including 'Donate to Charities' (mean 1.62, 1.88), 'Are not involved in abortion services' (mean $0.73,1.88$ ), and 'Does not produce or sell contraception' (mean $0.46,0.76$ ). This is to be expected given the nature of these attributes, however these items were less important overall in comparison to financial criteria and other social and ethical criteria such as 'Environmental management systems' (mean 2.61, 2.60). In fact both groups rate 'Does not pollute', 'Environmental management systems (EMS)', 'Fair treatment of workers', 'Equal opportunity' and 'Does not experiment on animals' as more important than any of the variables for which a significant difference exists. This seems to suggest that while there are some differences, the most important considerations in an investment decision are similar for both REL 1 and REL 2. The final group of criteria contained three information criteria. The two groups generally agreed as to the importance of these attributes with no statistically significant differences evident. Again the criteria were not as important as the financial criteria nor some of the social and ethical criteria discussed above.

To further tease out the differences between the two groups, each sub-sample was further partitioned by gender, giving a male and female sub-grouping within each. Gender has been shown to be an important factor that influences investment decision-making with women being more risk-averse and employing different decision-making strategies when making financial decisions compared to men (Barber \& Odean 2001; Powell \& Ansic 1997). Estes and Hosseini (1988) also demonstrated that gender was the most important explanatory factor affecting confidence in investment decisions. Females were less confident than males after controlling for the effects of other intervening variables such as age, education, knowledge and experience. Furthermore, Stinerock, Stern and Solomon (1991) found that women had a lower risk preference and a higher degree of anxiety in financial decisions than men. In addition, Miller and Stark (2002) found that women are more committed to religion because they are more risk-adverse. The analysis of the differences between the level of importance placed on each of these attitude variables showed that gender is a factor, both when considering attitude to investing as a whole (as per the prior literature) and when considering gender and religiosity together. 
Table 4

Attitudes to Investment Criteria

\begin{tabular}{|c|c|c|c|c|c|c|}
\hline Investment Criteria & $\begin{array}{c}\text { REL } 1 \text { v } \\
\text { REL } 2\end{array}$ & $\begin{array}{l}\text { All Male v } \\
\text { All Female }\end{array}$ & $\begin{array}{l}\text { REL } 1 \\
\text { M v F }\end{array}$ & $\begin{array}{l}\text { REL } 2 \\
\text { M v F }\end{array}$ & $\begin{array}{c}\text { Male } \\
\text { REL } 1 \text { v REL 2 }\end{array}$ & $\begin{array}{c}\text { Female } \\
\text { REL } 1 \text { v REL } 2\end{array}$ \\
\hline \multicolumn{7}{|l|}{ Financial Criteria } \\
\hline Perform above the average & -0.986 & 0.521 & 0.407 & 0.498 & -0.717 & -0.494 \\
\hline Good rating from analysts & 0.719 & 0.558 & 1.947 & -1.292 & $2.388^{*}$ & -0.634 \\
\hline Low entry fees & 0.022 & $2.932^{* *}$ & $3.799^{* *}$ & 0.522 & 1.587 & -0.930 \\
\hline Low ongoing fees & -1.122 & 0.908 & 1.644 & -0.350 & 0.271 & -1.626 \\
\hline \multicolumn{7}{|l|}{ General Criteria } \\
\hline Australian & $-2.835^{* *}$ & -1.409 & -1.216 & -0.838 & $-1.983^{*}$ & -1.873 \\
\hline Household names & $-2.991^{* *}$ & -1.126 & -0.555 & -1.187 & -1.591 & $-2.623^{* *}$ \\
\hline Old established companies & $-2.922^{* *}$ & $-2.100^{*}$ & -0.899 & $-2.296^{*}$ & -1.164 & $-2.923^{* *}$ \\
\hline \multicolumn{7}{|l|}{ Social and Ethical Criteria } \\
\hline Does not produce or sell alcohol & -1.894 & $-2.524^{*}$ & $-2.052^{*}$ & -1.520 & -1.269 & -1.090 \\
\hline Does not produce or sell weapons or defence & -1.144 & $-5.101^{* *}$ & $-3.472^{* *}$ & $-3.999^{* *}$ & -0.075 & -1.260 \\
\hline Does not produce or sell tobacco & -0.195 & $-3.330^{* *}$ & $-2.608^{* *}$ & $-2.058^{*}$ & -0.160 & 0.050 \\
\hline Sponsor the arts & -0.843 & $-2.031^{*}$ & -0.814 & $-2.519^{*}$ & 0.685 & -1.558 \\
\hline Donate to charities & $-2.062^{* *}$ & $-3.950^{* *}$ & $-2.534^{*}$ & $-3.519^{* *}$ & -0.658 & $-2.060^{*}$ \\
\hline Are not involved in abortion services & $-7.728^{* *}$ & 0.110 & -0.938 & 0.578 & $-5.989^{* *}$ & $-5.019^{* *}$ \\
\hline Good waste management practices & 0.039 & $-2.254^{*}$ & $-2.120^{*}$ & -1.101 & -0.434 & 0.488 \\
\hline Good relationships with indigenous people & -0.716 & $-2.495^{*}$ & $-2.200^{*}$ & -1.448 & -0.589 & 0.013 \\
\hline Treat all workers fairly & -0.552 & $-2.508^{*}$ & $-2.160^{*}$ & -1.481 & -0.557 & 0.035 \\
\hline Environmental management policies and practices & 0.065 & $-3.124^{* *}$ & $-2.191^{*}$ & $-2.481^{*}$ & 0.221 & 0.009 \\
\hline Does not pollute & -0.338 & $-2.962^{* *}$ & $-2.540^{*}$ & -1.685 & -0.491 & 0.166 \\
\hline Good relationships with local communities & -1.403 & -1.868 & -1.721 & -1.062 & -1.064 & -0.774 \\
\hline Support equal opportunity for all workers & -0.005 & $-2.968^{* *}$ & $-2.738^{* *}$ & -1.450 & -0.440 & 0.736 \\
\hline Does not produce or sell contraception & $-2.917^{* *}$ & 0.314 & -0.468 & 0.706 & $-2.527^{*}$ & -1.571 \\
\hline Does not experiment on animals & -0.542 & $.2 .730^{* *}$ & $-2.597^{* *}$ & -1.262 & -0.844 & 0.209 \\
\hline \multicolumn{7}{|l|}{ Information Criteria } \\
\hline A financial planner recommended the investment & -0.066 & 0.107 & -0.227 & 0.482 & -0.249 & 0.517 \\
\hline Good report in a magazine or newspaper & -0.836 & 0.404 & -0.212 & 0.914 & -0.907 & 0.162 \\
\hline A friend recommended the investment & 1.007 & -0.858 & 0.283 & -1.436 & 1.780 & 0.062 \\
\hline
\end{tabular}

This table presents summary results on the attitudes of investors to investments. Column 1 contains characteristics of investments which survey respondents allocated an importance score to using a 5 point scale where 5 is highly important and 1 is not important in terms of considering that item when selecting an investment. $T$-statistics indicating statistically significant differences between various combinations of the REL 1 and $R E L 2$ groups and gender are presented in Column 2 to Column $7{ }^{* *}$ represents a significant difference between the means of the importance ratings of the $R E L 1$ and $R E L 2$ respondents at the $p=0.01$ or greater level, based on a two tailed $t$-test. 
The $t$-statistics presented in Column 3 of Table 4 show that gender is an issue that influences investment decisions. This column compares males and females for the entire sample, which when compared to Column 2 (REL 1 compared with REL 2 as per Table 3), shows that there are 14 statistically significant differences between the groups. Twelve of these differences are social and ethical criteria including 'Does not sell or produce weapons', 'Donate to charities' and 'Does not experiment on animals', all of which are rated as more important by the female sub-group (Column 7) than the male sub-group (Column 6). The remaining two are 'Low entry fees' which men rate as more important, and 'Old established companies', which women rate as more important. This illustrates that gender is an important factor that influences the investment criteria that individuals consider important.

To examine religion and gender together each REL group is further split into male and female sub-groups (Column 4 and Column 5 of Table 4). For the REL 1 group no new differences between males and females arise (when compared to the full sample), and 12 of the 14 existing differences remain, although several of these are less statistically significantly different. The two that drop out are 'Old established companies' and 'Sponsor the arts'. Hence, there is a significant divergence between the importance placed on investment criteria, and particularly the social and ethical criteria, between men and women in the less religiously active group $R E L 1$. In the REL 2 group however, only 6 of the 14 differences remain, all of which are in favour of the female group (i.e. they rank the criteria more importantly than the men). These are 'Does not produce or sell weapons', 'Does not produce or sell tobacco' (slightly weaker), 'Sponsor the arts', 'Donate to charities', 'Environmental management policies' (also weaker), 'Old established companies' and 'Does not experiment on animals'.. Therefore, there are fewer differences between males and females in terms of the importance placed on investment criteria for those who are more religiously active ( $R E L$ 2). However, most of differences (5 out of 6) are again social and ethical criteria which women find more important.

A final test compares the males (females) from REL 1 with the males (females) of REL 2. Column 6 illustrates that there are 4 criteria that the males from each group disagree about (to a statistically significant extent) in terms of the importance of those factors for investment decision-making. The first of these is 'Good rating from analysts', which the less religiously active REL 1 males rate as more important, while 'Australian firms', 'Are not involved in abortion services', and 'Does not produce or sell contraception' are more important for the males of the REL 2 group. In terms of the female comparison there are 4 differences, all in favour of the REL 2 group, in the criteria 'Household names', 'Old established companies', 'Donate to charities' and 'Are not involved in abortion services'. This illustrates that religious activism does influence investment behaviour to some extent with issues that are traditionally sensitive/important to religious groups such as abortion, contraception, and donation to charities being more important investment attributes to those who are more religiously active in comparison to those who are not. Furthermore, religiously active females appear to be more conservative and risk-adverse, preferring companies that are household names and old established companies.

\section{Preferences}

The results for the analysis of the choice experiment bear out the attitude results, in that the utility scores of the factor levels and averaged importance of the factors themselves are similar for both treatment groups. In Table 5, it is evident that both REL 1 and REL 2 place more than twice as much importance on Performance (29.46, 29.56) and Star Rating (24.39, 20.38) than the other factors of Fees, Company type, Invests in and Does not invest in. 
Table 5

Conjoint Analysis Results: Religious Beliefs and Investing

\begin{tabular}{|c|c|c|c|c|c|c|c|c|}
\hline \multirow[t]{2}{*}{ Factor } & \multirow{2}{*}{\multicolumn{2}{|c|}{$\begin{array}{l}\text { REL } 1 \quad \text { REL } 2 \\
\text { Avg Importance }\end{array}$}} & \multirow[t]{2}{*}{ Level } & \multicolumn{2}{|c|}{ REL 1} & \multicolumn{2}{|c|}{ REL 2} & \multirow{2}{*}{$\begin{array}{l}\text { Diff in } \\
\text { Rank }\end{array}$} \\
\hline & & & & Utility & Rank & Utility & Rank & \\
\hline \multirow[t]{4}{*}{ Performance } & 29.46 & 29.56 & 8\% per annum & -1.4312 & 19 & -1.5572 & 19 & 0 \\
\hline & & & $10 \%$ per annum & -0.5391 & 15 & -0.6194 & 15 & 0 \\
\hline & & & $12 \%$ per annum & 0.3149 & 8 & 0.4371 & 7 & 1 \\
\hline & & & $14 \%$ per annum & 1.6554 & 1 & 1.7396 & 1 & 0 \\
\hline \multirow[t]{3}{*}{ Star rating } & 24.39 & 20.38 & Not rated & -1.0835 & 18 & -0.9292 & 18 & 0 \\
\hline & & & 2 Star & -0.3862 & 13 & -0.4142 & 12 & 1 \\
\hline & & & 4 star & 1.4697 & 2 & 1.3434 & 2 & 0 \\
\hline \multirow[t]{2}{*}{ Fees } & 12.28 & 16.47 & 0 entry, $2.49 \%$ pa and $4 \%$ exit & -0.6427 & 16 & -0.9184 & 17 & 1 \\
\hline & & & $4 \%$ entry, $1.95 \%$ pa and $0 \%$ exit & 0.6427 & 4 & 0.9184 & 4 & 0 \\
\hline \multirow[t]{2}{*}{ Company type } & 9.99 & 10.12 & Blue chip & 0.5226 & 6 & 0.5645 & 5 & 1 \\
\hline & & & Smaller companies & -0.5226 & 14 & -0.5645 & 14 & 0 \\
\hline \multirow[t]{4}{*}{ Invests in } & 9.44 & 12.78 & Environmental management systems & -0.1675 & 10 & -0.4391 & 13 & 3 \\
\hline & & & Company has good growth prospects & 0.6865 & 3 & 0.9858 & 3 & 0 \\
\hline & & & Good labour relations & -0.3010 & 12 & -0.2142 & 10 & 2 \\
\hline & & & Company has good management & -0.2180 & 11 & -0.3325 & 11 & 0 \\
\hline \multirow[t]{5}{*}{ Does not invest in } & 14.41 & 10.70 & Alcohol, tobacco \& gambling & 0.6355 & 5 & 0.5109 & 6 & 1 \\
\hline & & & $\begin{array}{l}\text { Companies that have had a loss in the past } \\
\text { year }\end{array}$ & -0.8731 & 17 & -0.6823 & 16 & 1 \\
\hline & & & $\begin{array}{l}\text { Companies that invest in, produce or sell } \\
\text { weapons and defence }\end{array}$ & 0.3779 & 7 & 0.0970 & 8 & 1 \\
\hline & & & $\begin{array}{l}\text { Companies that have a majority of executive } \\
\text { directors on the board }\end{array}$ & -0.1403 & 9 & 0.0744 & 9 & 0 \\
\hline & & & Constant & 4.6527 & & 4.6694 & & \\
\hline
\end{tabular}

This table presents summary conjoint analysis results on the factors that drive investor decision-making. Column 1 contains the 6 factors assessed with the various levels for each contained in Column 4. The average importance (as indicated by the investments selected by respondents) for male and female investors are presented in Column 2 and Column 3. Utility scores, reflecting the importance to investors, and the rank of these for both the REL 1 and REL 2 groups are presented in Column 5 to Column 8 . The final column presents the difference between the REL 1 and REL 2 ranks (Column 6 and Column 8). Both Pearson's $R$ and Kendall's tau were significant at the .0000 level. Kendall's tau for the holdouts for REL 2 was at an acceptable level, given the small number of holdouts that were used to measure this correlation (.667). For $R E L 2$, Kendall's tau for the holdouts was lower at .333 , which would suggest that this group did not respond to the holdouts in a predictable way, therefore the results for $R E L 1$ were not as predictable as those for REL 2. 
The utility scores for each of the factor levels also reflect a similarity between the groups, with similar rankings for each of the SRI criteria and for the general investment criteria. The results from a two-tailed $t$-test confirmed that there is no significant difference between the utility scores for each factor level for the two treatment groups. Therefore, it appears that both the groups prefer investments that have high returns, high star ratings, entry fees, no exit fees, good growth prospects, and are comprised of blue chip companies; and avoid companies in the business of alcohol, tobacco and gambling, irrespective of the level of religious activism. The fact that no significant difference exists between the groups for the level of importance placed on each of the factor levels shows that those who are more religious are no more likely to make decisions to invest in SRI than other people. Furthermore, even though both groups rated social and ethical criteria as being more important in the attitude section, these factor levels in the choice task were given relatively low importance in comparison to the attitudes expressed. Therefore, it appears that all investors are primarily concerned about investment performance, with other criteria subordinated.

Another interesting issue is that there appears to be no significant attitude-behaviour gap evidenced in our findings. In previous studies the attitudes of investors to investment criteria differed from actual investment choices made in a decision task. For example, those who are more environmentally active have been shown to place more importance on environmental, social and ethical criteria in an attitudes task, however they favoured financial performance criteria in the decision task (Vyvyan, Ng \& Brimble 2004). Similarly, females have been shown to place more importance on such criteria with the same result in a decision task (Vyvyan, Ng \& Brimble 2005). Interestingly, this is not the case for religious beliefs, indicating that this set of values do not significantly influence investment attitudes beyond that which cannot be explained by other variables such as gender. Furthermore, those who do hold and practise religious beliefs are true to their stated investment preferences when it comes to actual investing, unlike other groups.

\section{Concluding Remarks}

Investor behaviour is of increasing interest as the level of direct private investment increases. The literature has examined many issues that may influence the asset allocation decisions of investors, however there is little evidence that examines the role of religious activism in an investment context, particularly related to SRI where it would be more likely that those with strong religious beliefs would select investments that are in line with those beliefs.

When examining the attitudes of investors, we find that there is little difference between the attitudes of the more religious and the non-religious groups. Both groups rate financial criteria as more important than SRI criteria, and only those variables that are strongly influenced by religious philosophy are significantly different ('Donate to charities', 'Does not invest in abortion services' and 'Does not produce or sell contraception'). Interestingly, there is more homogeneity in terms of attitudes to investing and SRI between men and women in the more religious group than in the less religious group. Of further interest is that in this study women in the more religious group place more importance on the general criteria variables which could indicate that women who are more religious are more risk-adverse than other women. Both groups gave similar weight to each of the components of the choice task, and there were no significant differences found between the more and less religious groups. Financial performance was the key factor in both the choice task and the attitude survey for both groups. 
In summary, this indicates that financial performance is the most influential factor when it comes to investment decision-making. Our evidence suggests that this is even the case for those who indicate a high level of religious activism, suggesting that financial returns are still a prime influence in investment decision-making. Furthermore, SRI funds managers should concentrate on promoting the performance of their funds and that SRI attributes should be secondary, as they are unlikely to be used in the decision-making process of the retail managed funds investor.

However, the above findings should be interpreted in light of some of the limitations of this study. For example, the sample consisted of two large local organisations and this may have reduced the generalisability of these results. Another limitation relates to the potential respondent fatigue as participants were asked to evaluate 22 hypothetical funds and allocate investment funding according to their liking of the fund. Similarly, the use of mail questionnaires also limits the generalisability of findings since this kind of survey generally receives a poor response rate and the researchers are unable to check the responses given.

These findings also raise issues that require further investigation. In particular, to examine in more depth why religious beliefs do not significantly influence the investment decision-making process. Further, a better understanding of the influence of social norms on SRI decision-making will add to our knowledge. Finally, investigation of the attitude behaviour gap in other settings such as those with strong religious commitment may also prove useful. 


\section{References}

Agle, B R and Van Buren III, H J 1999, 'God and Mammon: The Modern Relationship', Business Ethics Quarterly, vol.9, no.4, pp63-582. http://dx.doi.org/10.2307/3857935

Ambachtsheer, J 2005, 'Socially Responsible Investing', Benefits and Compensation International, July/August, pp36-42.

Anderson, A \& Myers, D 2007, 'The Cost of Being Good', Review of Business, vol.28, no.1, pp5-17.

Angelidis, J \& Ibrahim, N 2004, 'An Exploratory Study of the Impact of Degree of Religiousness Upon an Individual's Corporate Social Responsiveness Orientation', Journal of Business Ethics, vol.51, pp119-128.

http://dx.doi.org/10.1023/B:BUSI.0000033606.27489.bf

Arjalies, D 2010, 'A Social Movement Perspective on Finance: How Socially Responsible Investment Mattered', Journal of Business Ethics, vol.92, pp57-78. http://dx.doi.org/10.1007/s10551-010-0634-7

ASSIRT 2002, Proactive Investor Survey.

Barber, B M \& Odean, T 2001, 'Boys will be boys: Gender, Overconfidence, and Common Stock Investment', The Quarterly Journal of Economics, vol.116, no.1, pp161-292. http://dx.doi.org/10.1162/003355301556400

Barnato, K 2010, 'Investing with a Conscience', Credit, September, pp28-31.

Barnett, T, Bass, K \& Brown, G 1996, 'Religiosity Ethical Ideology, and Intentions to Report a Peer's Wrongdoing', Journal of Business Ethics, vol.15, no.11, pp1161-1174. http://dx.doi.org/10.1007/BF00412815

Bauer, R, Koedijk, K \& Otten, R 2002, International Evidence on Ethical Mutual Fund Performance and Investment Style working paper, Lindberg Institute of Financial Economics.

Becker, E \& McVeigh, P 1999, 'Social Funds in the United States: Their History, Financial Performance and Social Impacts', The Second Heartland Labour - Capital Conference, April 29-30, Washington, DC.

Bengtsson, E 2008, ‘A History of Scandinavian Socially Responsible Investing', Journal of Business Ethics, vol.82, pp969-983. http://dx.doi.org/10.1007/s10551-007-9606-y

Benson, K, Brailsford, T \& Humphrey, J 2006, 'Do Socially Responsible Fund Managers Really Invest Differently?', Journal of Business Ethics, vol.65, pp337-357. http://dx.doi.org/10.1007/s10551-006-0003-8

Brimble, M A, Kremmer, M \& Tahir, I 2010, 'The Impact of Informed Religiosity on Portfolio Formation', Review of Islamic Economics, vol.14, no.1, pp5-25.

Cacioppe, R, Forster, F \& Fox, M 2008, 'A Survey of Mangers' Perceptions of Corporate Ethics and Social Responsibility and Actions that may Affect Companies' Success', Journal of Business Ethics, vol.82, (3) pp681-700. http://dx.doi.org/10.1007/s10551007-9586-y

Chung, J \& Monroe, G 2003, 'Exploring Social Desirability Bias', Journal of Business Ethics, vol.44, (4) pp291.

Clark-Murphy, M \& Soutar, G 2003, 'What Individual Investors Value: Some Australian Evidence', Journal of Economic Psychology, vol.25, no.4, pp539-555. http://dx.doi.org/10.1016/S0167-4870(03)00056-4

Conroy, S J \& Emerson, T L N 2004, 'Business Ethics and Religion: Religiosity as a Predictor of Ethical Awareness among Students', Journal of Business Ethics, vol.50, pp383-396. http://dx.doi.org/10.1023/B:BUSI.0000025040.41263.09

Corporations Act 2001 (Commonwealth of Australia), s 1013D 
Cortez, M, Silva, F \& Areal, N 2009, 'The Performance of European Socially Responsible Funds', Journal of Business Ethics, vol.87, pp573-588.

http://dx.doi.org/10.1007/s10551-008-9959-x

Cummings, L S 2000, 'The Financial Performance of Ethical Investment Trusts: An Australian Perspective', Journal of Business Ethics, May 2000, vol.25, no.1, pp79-92. http://dx.doi.org/10.1023/A:1006102802904

Dale, H 2007, 'SRI Firmly on the Agenda', Socially Responsible Investing, October, p42.

Equator Principles, available at www.equator-principles.com, accessed 7/1/13.

Estes, R \& Hosseini, J 1988, 'The Gender Gap on Wall Street: An Empirical Analysis of Confidence in Investment Decision Making', The Journal of Psychology, vol.122, no.6, pp577-590. http://dx.doi.org/10.1080/00223980.1988.9915532

Financial Services Reform Act 2002 (Commonwealth of Australia).

Guerard, J 1997, 'Additional evidence on the cost of being socially responsible in investing', Journal of Investing, vol.6, no.4, p31. http://dx.doi.org/10.3905/joi.1997.408433

Hair, J, Anderson, R, Tatham, R \& Black, W 1998, Multivariate Data Analysis, $5^{\text {th }}$ edn, Prentice Hall International Inc, Englewood Cliffs, NJ.

Henningsen, C 2002, 'Investing as if the World Really Mattered', Corporate Environmental Strategy, vol.9 (2), 163-171.Hutton, B, D’Antonio, L \& Johnson, T 1998, 'Socially Responsible Investing - Growing Issues and New Opportunities', Business and Society, vol.37, pp281-305.

Jones, R 2009, 'Money Management: Fair Ground', Money Management, 1 December, p10..

Kinder, P \& Domini, A 1997, 'Social Screenings: Paradigms Old and New', Journal of Investing, vol.6 (4), pp12-21. http://dx.doi.org/10.3905/joi.1997.408443

Kinder, P, Lydenberg, S \& Domini, A 1993, Investing for Good: Making Money While Being Socially Responsible, Harper Business, New York.

Knoll, M S 2002, 'Ethical Screening in Modern Financial Markets: The Conflicting Claims Underlying Socially Responsible Investment', The Business Lawyer, vol.57, February, pp681-726.

Resnik Communications/KPMG Consulting (2000), Money Where Your Mouth Is SydneyKreander, N, Gray, R, Power, D \& Sinclair, C 2002, 'The Financial Performance of European Ethical Funds 1996-1998', Journal of Accounting and Finance, vol.1, pp3-22.

The Mays Report, 2003. Corporate Sustainability - an Investor Perspective, Australian Commonwealth Government.

Miller, S \& Stark, R 2002, 'Gender and Religiousness: Can Socialization Explanations Be Saved?', The American Journal of Sociology, vol.107, no.6, pp1399-1423. http://dx.doi.org/10.1086/342557

Mohr, L, Webb, D \& Harris, K 2001, 'Do Consumers Expect Companies to be Socially Responsible? The Impact of Corporate Social Responsibility on Buying Behaviour', Journal of Consumer Affairs, vol.35, no.1, p45-72. http://dx.doi.org/10.1111/j.17456606.2001.tb00102.x

The Natural Marketing Institute 2003, An Excerpt from: Understanding the LOHAS Consumer Report - A Focus on Socially Responsible Investing (LOHAS Consumer Report), June, www.lohas.org.

Neumann, W L 2003, Social Research Methods, $5^{\text {th }}$ ed, Allyn and Bacon, Boston.

Potts, D 2010, 'Profit from saving the world', Sun Herald, 31 January, p48.

Powell, M \& Ansic, D 1997, 'Gender differences in risk behaviour in financial decisionmaking: An experimental analysis', Journal of Economic Psychology, vol.18 (6), pp605-628. http://dx.doi.org/10.1016/S0167-4870(97)00026-3 
Responsible Investment Association Australasia (RIAA) 2010, Responsible Investment 2010, www.responsibleinvestment.org.

Ruf, B, Krishnamurty, M, Brown, R, Janney, J \& Paul, K 2001, ‘An Empirical Investigation of the Relationship Between Change in Corporate Social Performance and Financial Performance: A Stakeholder Theory Perspective', Journal of Business Ethics, vol.32, no.2, pp143-156. http://dx.doi.org/10.1023/A:1010786912118

Saulwick \& Associates 2001, Shareholders Project: A Quantitative Study of Shareholder Attitudes to Investment Related Issues, Report No. 2, available at www.ethics.org.au.

Schwartz, M S 2003, 'The "Ethics” of Ethical Investing', Journal of Business Ethics, vol.43 (3), pp195-213. http://dx.doi.org/10.1023/A:1022933912939

Socially Responsible Investing Guidelines, 2002, Australian Securities and Investments Commission.

Star, M 2008, 'Socially Responsible Investment and Pro-Social Change', Journal of Economic Issues, vol.42, no.1, pp51-73.

Stinerock, R, Stern, B, \& Solomon, M 1991, 'Sex and money: Gender differences in the use of surrogate consumers for financial decision making', Journal of Professional Services Marketing, vol.7, no.2, pp167-182. http://dx.doi.org/10.1300/J090v07n02_15

Terpstra, D, Rozell, E \& Robinson, R 1993, 'The Influence of Personality and Demographic Variables on Ethical Decisions Related to Insider Trading', Journal of Psychology, vol.127, no.4, pp375-390. http://dx.doi.org/10.1080/00223980.1993.9915573

Tippett, J \& Leung, P 2001, 'Defining Ethical Investment and its Demography in Australia', Australian Accounting Review, vol.11, no.3, pp44-55. ttp://dx.doi.org/10.1111/j.1835-2561.2002.tb00389.x

United Nations Principles of Responsible Investment (UNPRI). 2012, www.pri.org, accessed 7/1/2013.

Vyvyan, V, Ng, C \& Brimble, M 2004, 'Socially Responsible Investing: Green Attitudes and Grey Choices', Paper presented at the Inter-Disciplinary CSR Research Conference, 22-23 October, University of Nottingham, UK.

Vyvyan, V, Ng, C \& Brimble, M 2005, 'The Influence of Gender on the SRI Decision Making Process: A Study of Attitudes and Preferences using Conjoint Analysis', Journal of Accounting and Finance, vol.4, pp17-34.

Watmore, M \& Bradley, L 2001, The Rothschild Report - Ethical Investing, a Study into Current Perceptions., Australia.

Williams, G 2007, 'Some Determinants of the Socially Responsible Investment Decision: A Cross Country Study’, The Journal of Behavioural Finance, vol.8, no.1, pp43-57. http://dx.doi.org/10.1080/15427560709337016

Wolkomir, M, Futreal, M, Woodrum, E \& Hoban, T, 1997, 'Substantive Religious Belief and Environmentalism’, Social Science Quarterly, vol.78, no.1, pp96-108.

Wright, C 2003, 'The problem with doing the right thing', The Weekend Australian Financial Review, 17-18 May, p39. 
AABFJ | Volume 7, no. 1, 2013 